\title{
Exclusion of PINKI as candidate gene for the late-onset form of Parkinson's disease in two European populations
} Anna Melissa Schlitter*1, Martin Kurz²,3, Jan P Larsen"3 , Dirk Woitalla4, Thomas Mueller ${ }^{4}$, Joerg T Epplen ${ }^{1}$ and Gabriele Dekomien ${ }^{1}$

\author{
Address: ${ }^{1}$ Department of Human Genetics, Ruhr-University Bochum, Germany, ${ }^{2}$ Department of Neurology, Heinrich-Heine-University \\ Düsseldorf, Germany, ${ }^{3}$ Department of Neurology, Stavanger University Hospital, Norway and ${ }^{4}$ Department of Neurology, St. Josef-Hospital, Ruhr- \\ University Bochum, Germany \\ Email: Anna Melissa Schlitter* - schlitter@gmx.net; Martin Kurz - kurzmartin@gmx.net; Jan P Larsen - jpl@sir.no; \\ Dirk Woitalla - dirk.woitalla@rub.de; Thomas Mueller - thomas.mueller@rub.de; Joerg T Epplen - joerg.t.epplen@rub.de; \\ Gabriele Dekomien - gabriele.dekomien@rub.de \\ * Corresponding author
}

Published: I4 December 2005

Journal of Negative Results in BioMedicine 2005, 4:10 doi:10.1 186/1477-5751-4-10

This article is available from: http://www.jnrbm.com/content/4/I/10

(C) 2005 Schlitter et al; licensee BioMed Central Ltd.

This is an Open Access article distributed under the terms of the Creative Commons Attribution License (http://creativecommons.org/licenses/by/2.0), which permits unrestricted use, distribution, and reproduction in any medium, provided the original work is properly cited.
Received: 10 July 2005

Accepted: 14 December 2005

\begin{abstract}
Background: Parkinson's disease (PD) is the second most common neurodegenerative disorder. Recently, mutations in the PINKI (PARK6) gene were shown to rarely cause autosomal-recessively transmitted, early-onset parkinsonism. In order to evaluate whether PINKI contributes to the risk of common late-onset PD we analysed PINKI sequence variations. A German (85 patients) and a Norwegian cohort ( 90 patients) suffering from late-onset PD were screened for mutations and single nucleotide polymorphisms (SNPs) in the PINKI gene. Both cohorts consist of wellcharacterized patients presenting a positive family history of PD in $\sim 17 \%$. Investigations were performed by single strand conformation polymorphism (SSCP), denaturating high performance liquid chromatography (DHPLC) and sequencing analyses. SNP frequencies were compared by the $\chi^{2}$ test
\end{abstract}

Results: Several common SNPs were identified in our cohorts, including a recently identified coding variant (QII5L) in exon I. Genotyping of the QII5L variation did not reveal significant frequency differences between patients and controls. Pathogenic mutations in the PINKI gene were not identified, neither in the German nor in the Norwegian cohort.

Conclusion: Sequence variation in the PINKI gene appears to play a marginal quantitative role in the pathogenesis of the late-onset form of PD, in German and Norwegian cohorts, if at all.

\section{Background}

$\mathrm{PD}$ is the second most common neurodegenerative disorder after Alzheimer disease affecting more than $1 \%$ of the population by the age of 65 years. Mutations in the alphasynuclein (PARK1), Parkin (PARK2) and DJ-1 (PARK7) gene cause fairly rare familial forms of PD characterized by an early age of onset. Mutations in the recently identi- fied LRRK2 (PARK8) gene, especially the common mutation G2019S, occur more frequently in patients suffering from early as well as late-onset PD [1,2]. Recently, mutations in the PINK1 (PARK6) gene were shown to cause autosomal recessively transmitted early-onset parkinsonism $[3,4]$. The PINK1 (PTEN-induced kinase 1) gene encodes a putative protein kinase. The protein is targeted 
Table I: Allelic frequencies of identified SNPs in Norwegian (NW) and German (G) patient cohorts

\begin{tabular}{|c|c|c|c|c|}
\hline \multirow[t]{2}{*}{ Exon } & \multirow[t]{2}{*}{ Sequence variation } & \multicolumn{2}{|c|}{ Allelic frequencies } & \multirow{2}{*}{$\begin{array}{l}\text { P-value *distribution is } \\
\text { significant }\end{array}$} \\
\hline & & NW & G & \\
\hline I & QII5L & 0.072 & 0.035 & 0.13 \\
\hline I & L63L & 0.083 & 0.218 & $0.0004 *$ \\
\hline 5 & Ivs $4-5 A>G$ & 0.017 & 0.091 & $0.002 *$ \\
\hline 6 & Ivs6+43C>T & 0.041 & 0.102 & $0.029 *$ \\
\hline 8 & N52IT & 0.128 & 0.188 & 0.13 \\
\hline 8 & c. $1783 \mathrm{~A}>\mathrm{T}$ & 0.201 & 0.2 & 0.98 \\
\hline
\end{tabular}

to mitochondria and shows a serine-threonine kinase domain with homology to kinases of the $\mathrm{Ca}^{2+} / \mathrm{calmodu}-$ lin family[3]. It appears to exert protective effects against cellular stress within mitochondria[3]. These findings link mitochondria directly to the pathogenesis of PD $[3,5]$. An additional link between mitochondrial dysfunction and PD is obvious via the identification of disease causing mutations in the Omi/HtrA2 gene [6]. The hypothesis of mitochondrial impairment was further emphasized by postmortem studies of PD brains [7] and observation of PD syndromes after intoxication with mitochondrial complex I inhibitors, such as MPTP (1-methyl-4-phenyl1,2,3,6-tetrahydropyridine) and rotenone [8]. Mutations in the PINK1 gene are the second most common cause of autosomal-recessively inherited early-onset PD after mutations in the Parkin gene. On the other hand, strong evidence was reported for a possible role of Parkin gene variations in the late-onset form of PD (age of onset $>45$ years): Parkin mutations appear to contribute to the common late-onset form and mutations, especially in exon 7 in heterozygous state, may play a role as susceptibility alleles for sporadic PD $[9,10]$. The question arises as to whether the PINK1 gene is also a candidate gene for lateonset forms of Parkinson's disease, similar to the suggested role of the Parkin gene.

Here we report of a population-based analysis of sequence variations within the PINK1 gene. The German cohort includes 85 patients suffering from late-onset form of PD and represents a modern urban population with a genetic heterogeneity. In contrast, the Norwegian cohort represents a more homogeneous population [11] and includes 90 patients suffering from late-onset form of PD.

\section{Results}

All 8 coding exons of the PINK1 gene were screened for sequence variation using SSCP and sequencing analyses. Several SNPs were identified in our cohorts (L63L, Q115L, Ivs4-5A>G het, Ivs6+43C $>\mathrm{T}$ het, N521T, c.1783A $>\mathrm{T}$ ). Allelic frequencies of several SNPs differed significantly between the two European cohorts confirming homogeneity of the Norwegian cohort (Table 1). Patients and controls were genotyped for the recently identified variation Q115L [12] using DHPLC analysis (Table 2). The observed frequencies did not differ significantly between patients and controls, neither in the German $(\mathrm{p}=0.27)$ nor in the Norwegian cohort ( $\mathrm{p}=0.8)$. This screening did not reveal any disease-relevant mutation in our cohorts.

\section{Discussion}

As recently shown, mutations in the PINK1 gene rarely cause autosomal-recessively transmitted PD [3]. Besides an early age of onset, the observed clinical symptoms in PD caused by PINK1 are similar to symptoms in idiopathic PD.

In this population-based study, we investigated whether sequence variations in the PINK1 gene play a role in the late-onset form of PD. A recently described variation (Q115L) of the PINK1 gene [12] was identified in the German and the Norwegian cohorts. We calculated allele frequencies in cases and controls and show here that the Q115L variant was not associated with late-onset PD in our study. These findings correspond to previously published data of no leading association of other coding SNPs within the PINK1 gene and PD [13]. In addition, several common SNPs were identified. We did not find any path-

Table 2: Genotyping of the QII5L variation

\begin{tabular}{lccccc}
\hline & $\begin{array}{l}\text { Norwegian cohort } \\
\text { Patients } \\
(\mathrm{n}=90)\end{array}$ & $\begin{array}{l}\text { Controls } \\
(\mathrm{n}=136)\end{array}$ & $\mathrm{P}$ & $\begin{array}{c}\text { German cohort } \\
\text { Patients } \\
(\mathrm{n}=85)\end{array}$ & $\begin{array}{c}\text { Controls } \\
(\mathrm{n}=210)\end{array}$ \\
\hline Q115 (Wildtype) & 80 & 118 & 0.8 & 79 & 190 \\
Q115L & 7 & 18 & 6 & 0 & 16 \\
LII5 & 3 & 0 & & 4 & 0.27 \\
\hline
\end{tabular}


Table 3: Primers for PINKI gene analysis

\begin{tabular}{|c|c|c|}
\hline Exon & Primer sequence & $\begin{array}{l}\text { Product } \\
\text { size (bp) }\end{array}$ \\
\hline Ex I & $\begin{array}{l}\text { F 5'-AAGTTTGTTGTGACCGGCG-3' } \\
\text { R 5'-CTTAGCTCCGTCCTCCGCT-3' }\end{array}$ & 507 \\
\hline Ex 2 & $\begin{array}{l}\text { F 5'-CCTTCCTAGGCTCCCTGGC-3' } \\
\text { R 5'-AAGATGGGCATTTTGAGAACATCT-3' }\end{array}$ & 387 \\
\hline Ex 3 & $\begin{array}{l}\text { F 5'-GCTTACAAGGAACTTACCATTCTGC-3' } \\
\text { R 5'-GTGCTGAGGACATAAGTGATGGAT-3' }\end{array}$ & 240 \\
\hline Ex 4 & $\begin{array}{l}\text { F 5'-GATGTATCAGCTCCAGGCCCT-3' } \\
\text { R 5'-TATTCTTTCCAGGTGTTGTATCTGATG-3' }\end{array}$ & 286 \\
\hline Ex 5 & $\begin{array}{l}\text { F 5'-AAACGTATTGGGAGTCGTCGA-3' } \\
\text { R 5'-CTCTAGTGCCCCTGGAGAGCT-3' }\end{array}$ & 266 \\
\hline Ex 6 & $\begin{array}{l}\text { F 5'-CGAGTCTCCTGCATTCAGTGG-3' } \\
\text { R 5'-GACATAGCAGGGCCTCTCAGAG-3' }\end{array}$ & 265 \\
\hline Ex 7 & $\begin{array}{l}\text { F 5'-TCAGGTGATGTGCAGGACATG-3' } \\
\text { R 5'-CAGAGGTTTCTACCCACACCG-3' }\end{array}$ & 358 \\
\hline Ex 8 & $\begin{array}{l}\text { F 5'-GGACCAGAGAAGGGAAGACCC-3' } \\
\text { R 5'-TCACGACACAGAGGATGCCA-3' }\end{array}$ & 410 \\
\hline
\end{tabular}

ogenic mutation of the PINK1 in our cohorts composed of patients suffering from late-onset form of PD. The risk to miss potential mutations was minimized by a well established and optimized SSCP analyses.

The most likely reason to explain the absence of mutations in our cohorts is the lack of influence of the PINK1 gene in the pathogenesis of late-onset PD. Individual tagging SNPs and tag-defined haplotypes in 500 PD patients likewise did not reveal associations with PD [14]. Future investigations should include screening of potential promoter as well as enhancer/silencer regions of the gene to finally exclude any lack of influence of PINK1 variation on PD manifestation. Yet, functional investigations of the PINK1 protein are necessary to identify potential interaction partners as candidates for additional mutation screening.

\section{Conclusion}

Investigations of other genes involved in the mitochondrial pathway of the PINK1 gene are necessary to evaluate the exact role of mitochondrial impairment for common forms of PD.

\section{Materials and methods \\ Patients and controls}

The Norwegian cohort $(n=90)$ consists of patients suffering from late-onset PD (median age of onset 64.4 years, range from 49 to 78 years, standard deviation 7.9) originated from the Stavanger area of Western Norway. This population is known to be genetically quite homogeneous [11] and has previously been described in several clinical PD studies [15,16]. 16.7\% of the patients presented a positive family history for PD concerning first degree rela- tives (siblings or parents). All patients meet the criteria for PD $[15,17]$ and were thoroughly clinically examined. An ethnically matched control group of healthy blood donors was recruited in Bergen, Norway. The German cohort $(n=85)$ consists of patients of the Ruhr area suffering from late-onset PD (median age of onset 58.7 years, range from 45 to 79 years, standard deviation 8.7) diagnosed according to the UK Brain Bank criteria [18]. 16.5\% of the patients presented a positive family history for PD concerning first degree relatives (siblings or parents). Ethnically matched control samples from senior healthy blood donors (median age 57.2 years, range from 42 to 68 years, standard deviation 5.7) were recruited at the neighbouring University Hospital of Essen (Germany). Population stratification was excluded for the controls by multiple microsatellites analyses. After receiving informed consent from the patients, peripheral blood samples were taken and genomic DNA was extracted following standard protocols. German (Bochum and Düsseldorf) and Norwegian (Bergen) ethics committees approved this study.

\section{SSCP, DHPLC, sequencing}

The 8 coding exons of the PINK1 gene were amplified by polymerase chain reaction (PCR) in all patients using designed primer pairs adapted to the SSCP technique (Table 3). SSCP analysis according to standard procedure [19] was used to identify mutations and SNPs. In order to optimize mutation screening by SSCP analyses, PCR products were digested with different restriction enzymes depending on the lengths of their fragments [19] and screened in two different conditions. Selected samples with band shifts evidenced in SSCP analyses were confirmed by direct sequencing. The sequence reactions were run on an automated DNA sequencer (Applied Biosystems 377 XL, Foster City, USA) and analyzed with the ABI Prism $^{\mathrm{TM}} 377 \mathrm{XL}$ collection and convenient sequencing analysis software. SNP frequencies of the Q115L variation in patients and controls were determinated by using DHPLC analyses $\left(\right.$ WAVE $^{\circledR}$ system, Cheshire, UK, using software Wavemaker 4.1) according to established procedures.

\section{Statistical analyses}

SNP frequencies were compared by the $\chi^{2}$ test. We considered P-values $<0.05$ as significant.

\section{Authors' contributions}

AMS carried out the molecular genetic studies, performed the statistical analysis and drafted the manuscript. MK participated in devising the study based on thoroughly clinical analysis of the patients. JPL supervised data collection and diagnosis of the Norwegian cohort. DW and TM provided the samples and performed clinical diagnostics of the German patient group. JTE conceived of the study, and participated in its design and coordination and 
helped to draft the manuscript. GD supervised AMS, especially the molecular studies. All authors read and approved the final manuscript.

\section{Acknowledgements}

We sincerely thank all the participants in this study. We also thank Dr. O.B. Tysnes (Department of Neurology, Haukeland University Hospital, Bergen, Norway) for providing control samples. AMS gratefully acknowledges an Alma and Heinrich Vogelsang Foundation fellowship.

\section{References}

I. Gilks WP, Abou-Sleiman PM, Gandhi S, Jain S, Singleton A, Lees AJ, Shaw K, Bhatia KP, Bonifati V, Quinn NP, Lynch J, Healy DG, Holton JL, Revesz T, Wood NW: A common LRRK2 mutation in idiopathic Parkinson's disease. Lancet 2005, 365:4I5-4I6.

2. Di Fonzo A, Rohe CF, Ferreira J, Chien HF, Vacca L, Stocchi F, Guedes L, Fabrizio E, Manfredi M, Vanacore N, Goldwurm S, Breedveld G, Sampaio C, Meco G, Barbosa E, Oostra BA, Bonifati V: A frequent LRRK2 gene mutation associated with autosomal dominant Parkinson's disease. Lancet 2005, 365:4I 2-4I 5.

3. Valente EM, Abou-Sleiman PM, Caputo V, Muqit MM, Harvey K, Gispert S, Ali Z, Del Turco D, Bentivoglio AR, Healy DG, Albanese A, Nussbaum R, Gonzalez-Maldonado R, Deller T, Salvi S, Cortelli P, Gilks WP, Latchman DS, Harvey RJ, Dallapiccola B, Auburger G, Wood NW: Hereditary early-onset Parkinson's disease caused by mutations in PINKI. Science 2004, 304: I I58-I I 60.

4. Rogaeva E, Johnson J, Lang AE, Gulick C, Gwinn-Hardy K, Kawarai T, Sato C, Morgan A, Werner J, Nussbaum R, Petit A, Okun MS, Mclnerney A, Mandel R, Groen JL, Fernandez HH, Postuma R, Foote KD, Salehi-Rad S, Liang Y, Reimsnider S, Tandon A, Hardy J, St GeorgeHyslop P, Singleton AB: Analysis of the PINKI gene in a large cohort of cases with Parkinson disease. Arch Neurol 2004, 6I:1898-1904.

5. Shen J, Cookson MR: Mitochondria and dopamine: new insights into recessive parkinsonism. Neuron 2004, 43:30I-304.

6. Strauss KM, Martins LM, Plun-Favreau H, Marx FP, Kautzmann S, Berg D, Gasser T, Wszolek Z, Muller T, Bornemann A, Wolburg H, Downward J, Riess O, Schulz JB, Kruger R: Loss of function mutations in the gene encoding Omi/HtrA2 in Parkinson's disease. Hum Mol Genet 2005.

7. Beal MF: Mitochondria, oxidative damage, and inflammation in Parkinson's disease. Ann N Y Acad Sci 2003, 991 : | 20-131.

8. Dauer W, Przedborski S: Parkinson's disease: mechanisms and models. Neuron 2003, 39:889-909.

9. Foroud T, Uniacke SK, Liu L, Pankratz N, Rudolph A, Halter C, Shults C, Marder K, Conneally PM, Nichols WC, Parkinson Study G: Heterozygosity for a mutation in the parkin gene leads to later onset Parkinson disease. Neurology 2003, 60:796-80I.

10. Oliveira SA, Scott WK, Martin ER, Nance MA, Watts RL, Hubble JP, Koller WC, Pahwa R, Stern MB, Hiner BC, Ondo WG, Allen FHJ, Scott BL, Goetz CG, Small GW, Mastaglia F, Stajich JM, Zhang F, Booze MW, Winn MP, Middleton LT, Haines JL, Pericak-Vance MA, Vance JM: Parkin mutations and susceptibility alleles in lateonset Parkinson's disease. [see comment]. Annals of Neurology 2003, 53:624-629.

11. Borg A DAHKMLHEMP: BRCAI 1675delA and II35insA account for one third of Norwegian familial breast-ovarian cancer and are associated with later disease onset than less frequent mutations. Dis Markers 1999, Oct; 15(1-3):79-84.:

12. Klein C, Djarmati A, Hedrich K, Schafer N, Scaglione C, Marchese R, Kock N, Schule B, Hiller A, Lohnau T, Winkler S, Wiegers K, Hering $R$, Bauer P, Riess O, Abbruzzese G, Martinelli P, Pramstaller PP: PINKI, Parkin, and DJ-I mutations in Italian patients with early-onset parkinsonism. Eur J Hum Genet 2005.

13. Groen JL, Kawarai T, Toulina A, Rivoiro C, Salehi-Rad S, Sato C, Morgan A, Liang Y, Postuma RB, St George-Hyslop P, Lang AE, Rogaeva E: Genetic association study of PINKI coding polymorphisms in Parkinson's disease. Neurosci Lett 2004, 372:226-229.

14. Healy DG, Abou-Sleiman PM, Ahmadi KR, Muqit MM, Bhatia KP, Quinn NP, Lees AJ, Latchmann DS, Goldstein DB, Wood NW: The gene responsible for PARK6 Parkinson's disease, PINKI, does not influence common forms of parkinsonism. Ann Neurol 2004, 56:329-335.
15. Kurz M, Alves G, Aarsland D, Larsen JP: Familial Parkinson's disease: a community-based study. European Journal of Neurology 2003, 10:159-163.

16. Tandberg E, Larsen JP, Nessler EG, Riise T, Aarli JA: The epidemiology of Parkinson's disease in the county of Rogaland, Norway. Movement Disorders 1995, 10:541-549.

17. Larsen JP, Dupont E, Tandberg E: Clinical diagnosis of Parkinson's disease. Proposal of diagnostic subgroups classified at different levels of confidence. Acta Neurologica Scandinavica 1994, 89:242-25।.

18. Hughes AJ, Daniel SE, Kilford L, Lees AJ: Accuracy of clinical diagnosis of idiopathic Parkinson's disease: a clinico-pathological study of 100 cases. J Neurol Neurosurg Psychiatry 1992, 55: I8I-I84.

19. Jaeckel S, Epplen JT, Kauth M, Miterski B, Tschentscher F, Epplen C: Polymerase chain reaction-single strand conformation polymorphism or how to detect reliably and efficiently each sequence variation in many samples and many genes. Electrophoresis 1998, 19:3055-3061.
Publish with Bio Med Central and every scientist can read your work free of charge

"BioMed Central will be the most significant development for disseminating the results of biomedical research in our lifetime. "

Sir Paul Nurse, Cancer Research UK

Your research papers will be:

- available free of charge to the entire biomedical community

- peer reviewed and published immediately upon acceptance

- cited in PubMed and archived on PubMed Central

- yours - you keep the copyright

Submit your manuscript here:

http://www.biomedcentral.com/info/publishing_adv.asp
BiolMedcentral 